\section{THE ADULTERATION OF ANNATTO.}

\section{To the Editor of The LATreET.}

SIR,-Since Mr. Redwood, in his very lame reply to my letter, objects to my version of what he said at the Pharmaceutical Society, and designates a portion of it as a "gross perversion of his statements," I am sure you will afford me the opportunity of showing from the pages of the Pharmaceutical Journal, which is under Mr. Redwood's management, and published since my letter was sent to you, wherein, and with whom, the gross perversion referred to lies.

Such being Mr. Redwood's connexion with the above publication, it is evident that his speech as now reported in that journal, after careful scrutiny and revision, must be regarded as conveying the most favourable view of what fell from him on a recent occasion, and of the opinions now entertained by him on the subject of the adulteration of annatto. What these are, appears from the following extracts from his speech, contained in the Pharmaceutical Journal for the current month. "He, Mr. Redwood, was disposed to think, however, that there was better grounds for assuming that copper had been intentionally introduced, than there was with regard to lead. He could conceive an object for introducing a small quantity of copper. Amongst the communications he had received from different parts of the country on the subject of annatto, was one from a chemist in Somersetshire, who states that a minute quantity of sulphate of copper had been found efficacious for preventing a defect which sometimes occurred in the cheese of that district, and he suggested that a salt of copper might have been introduced into the samples of annatto referred to with that object. This certainly was a subject worthy of careful investigation. The question was a debatable one, whether any quantity of sulphate of copper ought to be introduced into articles of food. In France, and other continental countries, in spite of the stringent laws which had been passed upon the subject, sulphate of copper was to the present day used, as our bakers used alum, in making bread. An extremely minute quantity produced the effect."

At page 323 of the same journal will be found a letter from Dr. Hassall, containing similar statements to those of my letter; this Mr. Redwood has passed over in silence, merely appending a short and unimportant note.

Dr. Hassall writes:- "With respect to the copper, it appears from Mr. Redwood's admission, that it, too, must be regarded as an intentional admixture," and again, "Mr. Redwood admitted that sulphate of copper is added to annatto for the purpose of making it keep better, and of preventing the growth of mould in cheese. Knowing as much as I do of the practices resorted to in the adulteration of various articles of consumption, I am not surprised at the use of that substance, but I am astonished that any one should defend its employment, and especially astonished was $\mathrm{I}$ at the reason assigned by $\mathrm{Mr}$. Redwood in justification of its use, mamely, that sulphate of copper was employed in Belgium in bread-making without baneful consequences."

I am sure it must strike everyone as something more than accidental that your sensitive correspondent should have allowed such remarks to be made without at once denying, or calling the attention of his readers to what in my letter ho pleases to call "a gross perversion of his statements."

It is still more remarkable that a gentleman who took notes of all Mr. Redwood said, should have given the same version of his statements. In truth, Sir, Mr. Redwood uttered what I have stated in my former communication, and not one word did he say, at that time, about his friend, the Somersetshire chemist; but finding, as I before observed, that his ardour to defend adulteration has seriously compromised himself, he now wishes to shift part of the responsibility to the shoulders of his friend the country chemist. I fairly stated that he finished his sentiments with a flourish; of course not at all meaning "to justify the use of such substances as sulphate of copper and lead; that the subject was one demanding a thorough investigation, doubtless; a debatable question, well fitted for such meetings as the present," \&c. Nevertheless, from all that occurred at the last meeting of the Pharmaceutical Society, I, with many others, came to the conclusion that Mr. Redwood attended that meeting with a determination to use his best endeavours to put down "the cry of adulteration of food."

If it was not so, then there must be some other very strong reason to induce a professor of chemistry and a teacher to get up and talk of the introduction of either small or large quantities of poison into articles of food as a "debatable question."
Why, Sir, the only place in which such a question can be made debatable is in a court of law, and before a jury of our countrymen. There, indeed, the acctsed may avail himself of the privilege of calling Mr. Redwood in his defence; but we should then have a proper opportunity of testing the value of his evidence in averting well-deserved punishment from the guilty adulterator.

In conclusion, I must be permitted to doubt the sincerity of the observations contained in the concluding paragraph of $\mathrm{Mr}$. Redwood's letter to you; and I fear any one reading his own version of the annatto adulteration question, must come to the same conclusion with myself. The line of defence taken, it can be clearly seen, is that of the paid and earnest advocate to win a case for his client. And what must we think of the sincerity of anyone, who writing upon the subject of annatto in the Pharmaceutical Journal for November, after enumerating the various substances, as flour, chalk, salt, red earth, turmeric, copper, \&c., with which Dr. Hassall had stated it to be adulterated, makes this remark, "The manufacturers deny that there is any truth in the statements which have been made." In December, the following month, we find Mr. Redwood boldly coming forward armed with the authority of these same manufacturers, and not only prepared to admit, but to justify these and other additions which impart, as he says, "to the annatto new properties, which make it more valuable."

Mr. Redwood is Jikewise for ignoring what he pleases to term minute quantities; these he considers not even worth the notice of analytical chemistry, much less microscopy. "What is the use of alarming the public mind, when one per cent. or traces of copper or lead are present? Wait until sufficient is found to endanger health, or a few deaths ensue; then it is time to make a fuss." This is the line of argument Mr. Redwood would advocate. What would he say of such cases as the following, - and we know not how often such cases arise in London from the same cause? I was hastily summoned to see a friend a few weeks since, who, after partaking of a hearty dinner, was seized with vomiting and other alarming symptoms. I inquired what he had taken for dinner, and the reply was, "Largely of cold roast-beef, with pickles." I asked to see the pickles, when a very green-looking jar of gherkins was placed before me. I took a well-polished steel knife, plunged it into the bottle, and in about ten minutes time I withdrew it coated with copper. I saw what had produced the mischief, treated the case accordingly, and had the satisfaction of seeing my friend quickly recover. I have no doubt the manufacturer, of these pickles would tell me that he has a perfect right to prepare his articles as he thinks best adapted to catch the eye, and may be to secure the greatest number of purchasers. Un. fortunately the look of the article too often decides the question with the public. Will Mr. Redwood allow me to inquire if asked by this manufacturer to endorse his proceedings, would he say for him what he has said for the annatto manufacturers, at page 305, Pharmaceutical Journal, "They were made for a legitimate object, and they fulfilled that object in an unobjectionable way."

Jan. 14, 1856

I remain, Sir, most obediently yours,

JABEZ HoGG.

\section{THE ADULTERATION OF FOOD QUESTION.} To the Editor of THE LaxceT.

SIR,-I was delighted to read so able and truthful a letter from your correspondent, Mr. Jabez Hogg, on the subject of "Annatto Adulteration," published in THE LANCET of Jan. 5th; and I for one will venture to assert, that the substance of that document is perfectly in accordance with what passed (almost word for word) at the last Pharmaceutical meeting in Bloomsbury-square.

Mr. Redwood's subsequent letter and reply to Mr. Jabez Hogg, is a gross misstatement put forth to the members of the Society and the public, and is, in fact, an "adulteration" of the plain facts elicited from the speakers at the Pharmaceutical meeting. How Mr. Redwood can conscientiously contradict the truths contained in Mr. Hogg's letter, is to me a mystery.

In upholding this system of fraud, Mr. Redwood is doing himself and the members of the Society inconceivable mischief. The real object of the Society- " to promote the advancement of Pharmacy"-will be entirely obliterated, if its professor still persists in his ridiculous attempts to support these abominable practices, to the injury of the medical profession and the public.

I am, Sir, your obedient servant,

Crawford-street, January, 1856. 